those in whom there was a confidant expectation that they could be rendered cancer free, has provided cohorts of patients staged T1NOMO with survival rates of up to $80 \%-90 \%$.

Competing interests None.

Provenance and peer review Commissioned; internally peer reviewed.

Published Online First 22 June 2012

Thorax 2012;67:759-761

doi:10.1136/thoraxjnl-2012-202006

\section{REFERENCES}

1. Treasure T, Dussek J, Eraut D, et al. The Critical Under-Provision of Thoracic Surgery in the UK: Report of a joint Working Group of The British Thoracic Society and The Society of Cardiothoracic Surgeons of Great Britain and Ireland. Society of Cardiothoracic Surgeons of Great Britain and Ireland, 2002. http:// www.scts.org/doc/6168

2. Partridge MR. Thoracic surgery in a crisis. BMJ 2002;324:376-7.

3. Rich AL, Tata LJ, Stanley RA, et al. Lung cancer in England: information from the National Lung Cancer Audit (LUCADA). Lung Cancer 2011;72:16-22.

4. Rich AL, Tata LJ, Free CM, et al. Inequalities in outcomes for non-small cell lung cancer: the influence of clinical characteristics and features of the local lung cancer service. Thorax 2011;66:1078-84.
5. Riaz SP, Linklater KM, Page R, et al. Recent trends in resection rates among non-small cell lung cancer patients in England. Thorax 2012;67:812-15.

6. Belcher JR. Thirty years of surgery for carcinoma of the bronchus. Thorax 1983:38:428-32.

7. Russell RC, Treasure T. Counting the cost of cancer surgery for advanced and metastatic disease. $\mathrm{Br} \mathrm{J}$ Surg 2012;99:449-50.

8. Fisher B. The surgical dilemma in the primary therapy of invasive breast cancer: a critical appraisal. Curr Probl Surg 1970;7:2-53.

9. Ellis H. If I had... If my wife had cancer of the breast. Br Med J 1978;1:896-7.

10. Veronesi U, Saccozzi R, Del Vecchio M, et al. Comparing radical mastectomy with quadrantectomy, axillary dissection, and radiotherapy in patients with small cancers of the breast. $N$ Engl J Med 1981;305:6-11.

11. Berwick DM. The science of improvement. JAMA 2008;299:1182-4

12. Treasure T, Hillerdal G, Utley M. LUCADA: a valuable resource but there are questions it cannot answer. Thorax 2011;66:1023-4.

13. Treasure $\mathbf{T}$, Utley $\mathbf{M}$. Ten traps for the unwary in surgical series: a case study in mesothelioma reports. J Thorac Cardiovasc Surg 2007;133:1414-18.

14. Utley M, Fiorentino F, Treasure T. Obtaining an upper estimate of the survival benefit associated with surgery for mesothelioma. Eur J Cardiothorac Surg 2010;38:241-4
15. Treasure $\mathbf{T}$, Lang-Lazdunski L, Waller $\mathrm{D}$, et al. Extra-pleural pneumonectomy versus no extra-pleural pneumonectomy for patients with malignant pleural mesothelioma: clinical outcomes of the Mesothelioma and Radical Surgery (MARS) randomised feasibility study. Lancet Oncol 2011:12:763-72.

16. Lilford RJ, Thornton JG, Braunholtz D. Clinical trials and rare diseases: a way out of a conundrum. $B M$ 1995;311:1621-5.

17. van Loon J, Grutters J, Macbeth F. Evaluation of novel radiotherapy technologies: what evidence is needed to assess their clinical and cost effectiveness, and how should we get it? Lancet Oncol 2012;13 e169-77

18. Treasure T, Morton D. GRIST: Growing Recruitment in Interventional and Surgical Trials. J $R$ Soc Med 2012:105:140-1.

19. Utley M, Paschalides C, Treasure T. Informing decisions concerning adjuvant chemotherapy following surgical resection for non-small cell lung cancer: a mathematical modelling study. Lung Cancer 2006;53:153-6.

20. Utley M, Treasure T, Linklater K, et al. Better out than in? The resection of pulmonary metastases from colorectal tumours. In: Xie X, Lorca F, Marcon E, eds. Operations Research for Health Care Engineering: Proceedings of the $33^{\text {rd }}$ International Conference on Operational Research Applied to Health Services. Saint-Etienne: Publications de l'Universitaire de SaintEtienne, 2008:493-500.

\title{
High sixes!
}

\section{Andrew Bush, ${ }^{1}$ lan Pavord ${ }^{2}$}

The release of the 2012 impact factors have been really encouraging, with Thorax rising to 6.84 , and the distance between ourselves and our nearest competitors, Chest and the European Respiratory Journal

${ }^{1}$ National Heart and Lung Institute, Imperial College,
London, UK. ${ }^{2}$ Glenfield Hospital, UK

Correspondence to Dr Andrew Bush, National Heart and Lung Institute, Imperial College, London, UK; a.bush@imperial.ac.uk widening (but congratulations to the ERJ for leaping into third place). We remain the second ranked respiratory journal in the world. This has only happened because of the great manuscripts submitted to us by so many good groups, and the tireless work of the Deputy and Associate Editors, the Editorial Board, so many who have given generously of their time to review the papers, and all the editorial staff. Huge thanks to you all, and please keep it up. We are not complacent, however, and we want to use this encouragement to spur us to higher levels of performance and an even better impact factor in the last 3 years of our tenure.

And the second of the high sixes? Thorax's answer to Tiger Woods (at least on the golf course), Ian Pavord, wishes it to be known that he has won the BTS Lipscomb Trophy for the 6th successive year. Always good to have someone conforming to the Ministerial stereotypes of Consultants!

\section{Competing interests None.}

Provenance and peer review Commissioned; internally peer reviewed.

Thorax 2012:67:761.

doi:10.1136/thoraxjnl-2012-202395 